\title{
The wisdom and apocalyptic layers of the Sayings Gospel Q: What is their significance?
}

P J Hartin

University of South Africa

\begin{abstract}
The wisdom and apocalyptic layers of the Sayings Gospel Q: What is their sifnificance?

New Testament scholarship over the past three decades has shown a growing interest in the Savings Gospel Q. Vielhauer's thesis on the secondary nature of the future Son of man sayings led to the conclusion that the apocalyptic element within the Sayings Gospel $Q$ was also secondary. This paper follows the work of Kloppenborg and examines the wisdom and apocalyptic layers of the Sayings Gospel $Q$. The examination argues that the prociamation of Jesus was directed first of all to the proclamation of a kingdom that was present. The apocalyptic understanding of a future, immediate end of the world was a later appropriation within a deuteronomistic framework that developed from sayings of Jesus that were interpreted in this way by the early church.
\end{abstract}

\section{THE SAYINGS GOSPEL $Q$}

For one hundred and fifty years scholars have argued that the earliest written Gospel was that of Mark. They have further argued that in composing their Gospels Matthew and Luke made use of the Gospel of Mark as well as another source which contained sayings of Jesus which they termed $\mathrm{Q}^{2}$. This two document hypothesis has been the backbone of studies on the Gospels ever since. The success of any hypothesis depends upon its ability to explain available data, and as such the two document hypothesis has demonstrated its fruitfulness.

The term 'Sayings Gospel Q' used throughout this paper needs some explanation. The source behind the Gospel of Matthew and Luke is variously designated as simply 'Q', or as 'The Sayings Source Q', or more recently 'The Sayings Gospel Q'. I prefer this latter title for a number of reasons. The term 'Gospel' is used deliberately in order to argue that this source represents a theology of Jesus which did not, as with the canonical Gospels, place its center upon the death and resurrection (which is totally absent from ' $Q$ '). 
Kümmel had argued that a narrative was essential to the designation of Gospel, because a collection of sayings could not simply bear this title. However, he has been proved wrong by 'The Gospel of Thomas' which is exactly that, a collection of sayings which bears the title of 'Gospel'. As with ' $Q$ ' the Gospel of Thomas also placed no interest in a theology of the death and resurrection of Jesus. Consequently, the designation of Gospel is not to be limited to one expression of its nature as occurs in the canonical Gospels, but is a wider designation for the theological significance of Jesus, wherever one may place the emphasis. What is characteristic of a Gospel is that it tries to give a theological perspective on Jesus and his teaching. In this sense ' $Q$ ' can with justification be termed a Gospel'3.

This view of ' $Q$ ' as a Gospel was already recognized by W D Davies who indicated that ' $Q$ ' bears witness to 'the crisis' initiated by the proclamation of Jesus and it is this crisis, which forms the center of the Gospel'. In arguing that ' $Q$ ' is a Gospel the purpose is to prevent this document from being relegated to the margins of New Testament study. Instead, one sees ' $Q$ ' as presenting the distinct theological viewpoint (different from other New Testament writings) of a group of early Christian Jews. As such it has great importance in the reconstruction of the history and thought of early Christianity.

\section{THE DOMINANT VIEW: THE APOCALYPTIC JESUS}

In recent years interest in the study of the Sayings Gospel $Q$ has attracted a growing interest of attention to the extent that one can speak of a rebirth of studies on the Sayings Gospel $Q^{5}$. This renewed interest in the Sayings Gospel $Q$ must be seen against the background of wider studies that have been done into the nature of the historical Jesus. At the turn of the century Johannes Weiss and Albert Schweitzer championed the understanding of Jesus as coming to proclaim and to establish a future eschatological kingdom. This future eschatological approach in interpreting the preaching and ministry of Jesus became the dominant consensus of New Testament scholarship for almost three-quarters of this century.

Rudolf Bultmann endorsed this perspective of Jesus, making it an almost unchallenged assumption of his theological understanding (see also Borg 1986:82; Robinson 1991:178-179). Jesus proclaimed a kingdom that was imminently expected to occur, which gave understanding to human existence calling his hearers to make an existential decision. Bultmann's followers continued to give importance to this understanding of eschatology in the preaching of Jesus. A good example of this is the work of Günther Bornkamm whose book, Jesus von Nazareth, became the standard scholarly work on Jesus for many decades. It was indeed Bornkamm and 
his students who kept the future eschatological interpretation alive. Even outside of Germany the domination of the future-eschatological understanding of Jesus' ministry was felt due to the influence of German scholarship.

One of the first challenges addressed to the ruling consensus of the eschatological Jesus came from Philipp Vielhauer. A Bultmannian himself, Vielhauer argued that early Christian traditions, related to the Son of man, were unrelated to those referring to the kingdom of God. He argued that the kingdom of God sayings were authentic Jesus sayings, while the Son of man sayings originated within the context of the early Church. A further chink in the armor of the eschatological consensus with regard to Jesus' proclamation was seen to come from sections of British scholarship. Dodd $(1961,1971)$ championed a 'realized eschatology' in place of a future eschatology.

In fact it was the challenge to the Son of man sayings which were to cause the undoing of the consensus related to the apocalyptic proclamation of Jesus. The real basis for such a proclamation rests upon the Son of man sayings, and if these are removed as coming from the early Church, then the argument for Jesus as an apocalyptic harbinger is thrown into severe question 6 .

At the same time the realization has grown that in Judaism of the time of Jesus there is no evidence for the phrase 'Son of man' being used in the form of a title for any messianic figure. Vermes has shown that the phrase 'Son of Man' in Aramaic was simply a common idiom referring to being human and that is the way Jesus' hearers would have understood it. From a different perspective Lindars (although he does not endorse the basis for Vermes' arguments) accepts his conclusions, namely that Jesus could not have used the phrase 'Son of man' in the sense of a title referring to a future eschatological figure. Without the Son of man sayings being authentic sayings of Jesus, there is no reason to see Jesus' proclamation of the kingdom as referring to an imminent future destruction of the world.

\section{IMPLICATIONS FOR THE SAYINGS GOSPEL Q}

All this has implications for the understanding of the Sayings Gospel $Q$. The themes of 'kingdom of God' and 'the imminent end of the world' did not originate together. While Jesus used the kingdom as a symbol to express God's past, present, and future relationship with humanity and the call to humanity to enter into that relationship, the apocalyptic stress originates later within the context of the early church which sees the need to stress the end of time event which ushers in a new relationship between God and humanity. 
Vielhauer's thesis made it possible for this new direction to emerge. With the emphasis upon the secondary nature of the future role of the Son of man, the emphasis on apocalyptic within the Sayings Gospel $Q$ has been seen to be seconda$\mathrm{ry}^{7}$. The question needed to be asked: 'What was the primary perspective of the Sayings Gospel Q'?

Vielhauer's position did gain support among a few important scholars within the context of 'Bultmann's school', such as E Haenchen, E Käsemann, and H Conzelmann. Conzelmann (1957:281) was one of the first to endorse the views of Vielhauer. However, others of 'Bultmann's School' did not go along with them. The most influential of these was Günther Bornkamm (1956:206-210) who argued for Jesus' understanding of an apocalyptic Son of man who will return. Nevertheless, it was these very scholars who were to have the largest impact in reviving studies on the Sayings Gospel Q over the past thirty years by contributing fresh and new approaches to the study of the Sayings Gospel Q. For example, Heinz Eduard Tödt (1959), in his study on Jesus as the Son of man, argued that essential to the understanding of the Sayings Gospel Q was the position of Jesus as the future Son of man. In other words Tödt saw the Sayings Gospel $Q$ as having a theology in its own right, something which had not been acknowledged until then (Tödt 1965:270). The significance of this cannot be stressed sufficiently: he showed that there were in existence in the early Christian Church independent kerygmas which differed from one another. It pronounced the death-knell to those views on the early Christian Church professing a monolithic Christian kerygma.

Odil Hannes Steck (1968:288) used the concept of Israel's deuteronomistic view of history to give form and understanding to the Sayings Gospel Q. Again the importance of trying to discover a uni ${ }^{\prime}$ jing theological principle is seen with regard to the Sayings Gospel Q. In the deuteronomistic tradition Israel surveyed its history which demonstrated an oscillation between obedience and disobedience to God. Consequently, a constant call to repent is addressed to Israel. Steck traces the history of this deuteronomistic movement up to the time of the New Testament. In the first half of the second century BCE it was this tradition which brought together different groups in opposition to the threats which their religion was experiencing. Steck sees this deuteronomistic overview of history as giving meaning to the present events in which $Q$ demonstrates a concern for the conversion of Israel ${ }^{8}$. Thereafter, the deuteronomistic tradition became the common property of a number of different groups within Israel, particularly those that were concerned with effecting a renewal within Israel ${ }^{9}$. Steck demonstrates that the Sayings Gospel $Q$ is a renewal movement that stands within this deuteronomisitic tradition. As Jacobson comments: 
That $Q$ stands within the deuteronomistic tradition seems evident. The elements constitutive of the deuteronomistic view of history are widely attested in $Q$. The basic concern - to call Israel to repent underlies both $\mathrm{Q}$ and the earlier deuteronomistic tradition. One may conclude, therefore, that the deuteronomistic view of history which comes to clear expression in Q 11:47-51 and 13:34-35 represents the theological framework undergirding a large part of the $Q$ material.

(Jacobson 1992:74)

Dieter Lührmann (1969) gave the studies on the Sayings Gospel Q a remarkably new spur of life in his identification of redactional activity in the Sayings Gospel $Q$. Not only is the Sayings Gospel Q seen to demonstrate a theology of its own (as Tödt and Steck had argued), but a redactional analysis of the Sayings Gospel $Q$ demonstrates that it has undergone a development in its composition. Lührmann identified the center of the redactional activity as occurring in the apocalyptic judgments that were uttered against 'this generation' because they had rejected the $Q$ proclamation. Here, Lührmann has also moved closer to Vielhauer's position namely that the apocalyptic dimension was a secondary element inserted by the early church into the proclamation of Jesus (Robinson 1991:183-184). In identifying layers in the Sayings Gospel Q, Lührmann has contributed greatly to further research on the Sayings Gospel Q.

Attention was drawn by Lührmann to the studies of Koester (1971:186) on the Gospel of Thomas which showed that it lacked any apocalyptic expectation in relation to the Son of man. Instead its focus lay on the eschatology of the Kingdom and the making known of divine wisdom. Lührmann noted its similarity to the Sayings Gospel Q, but he did not develop his thought any further. This was done by D Zeller $(1977,1982)$ who undertook a methodological consideration on the very nature of redaction. In the Sayings Gospel $Q$ he notes that redaction is evident in two kinds of activity: the interpretative expansion of material that is already in existence and the assembling or bringing together of these units (Zeller 1982:395-409). He argued that in order to be able to speak of a stage in the redaction of the Sayings Gospel $Q$, one is concerned not just with random editorial comments, but with a detailed activity that brings together into a unity large amounts of material and gives it a specific direction. Elsewhere, Zeller was able to identify a group of six clusters of sayings that had developed around a center of admonitions ${ }^{10}$. These six collections of sayings all have a sapiential emphasis.

Sigfried Schulz (1972) endeavored to plot the development of traditions within the Sayings Gospel $Q$ and by so doing identified two layers within the Sayings Gospel $Q$. The first layer was made up solely of sayings material (individual sayings as 
well as clusters and groupings of sayings (Schulz 1972:52-53, 57, 165). This early material belonged to the 'kerygma of the Jewish Christian Q community' in Palestine (Schulz 1972:166). The later material belonged to the kerygma of the $\mathbf{Q}$ community in Syria'11. The importance of Schulz's investigation lies in the fact that he has shown that the Sayings Gospel $Q$ is not a simple unity and that one has to account for the diversity within it ${ }^{12}$.

Kloppenborg (1987) became the culminating point of this line of development by subjecting the whole of the Sayings Gospel $Q$ to a literary analysis to identify its layering. Kloppenborg took seriously Koester's insight that the wisdom dimension was the oldest part of the Sayings Gospel Q, and Kloppenborg demonstrated this through his study ${ }^{13}$.

Noteworthy is the fact that of the six complexes of sayings identified by Zeller five of them are accepted by Kloppenborg as forming part of his first sapiential layer of the Sayings Gospel Q. To be noted as well is the independent study of Piper (1989) who also identified a group of six pre-Sayings Gospel Q collections of aphoristic sayings. Although not completely identical with the list of Kloppenborg, nevertheless the independent study of Piper lends support to the basic argument that there are layers in the Sayings Gospel $Q$, and that the basic layer is that of a collection of wisdom sayings (Robinson 1991:186).

\section{THE WISDOM LAYER OF THE SAYINGS GOSPEL $Q$}

The present state of studies on the Sayings Gospel $Q$ is greatly influenced by the work of Kloppenborg ${ }^{14}$. I wish to pay attention briefly to each one of these layers of the Sayings Gospel as identified by Kloppenborg, namely the Wisdom and Apocalyptic layers, in order to draw out the significance of this stratification.

The earliest stratum of $Q$ has been called a sapiential, instructional layer ${ }^{15}$ made up of six sapiential speeches (Kloppenborg 1987:101). The main theme that runs throughout the whole composition is related to the life of a follower or a disciple. It contains instruction that is directed to the disciples as members of the $Q$ community on the demands and way of life that they are to embrace. All wisdom literature had as its aim a specific audience to whom it wished to communicate its teaching: most often it was the instruction that was given by a father to his son, or a king to his courtiers. The instruction was always practically determined with the aim of providing direction for the one receiving the instruction on how to lead his/her life successfully. It was the communication of the wisdom of experience from those who had acquired this wisdom to those who were young and desirous of obtaining this wisdom. 


\subsection{Sapiential Speeches in Q1}

The Sayings Gospel $Q$ does not consist in a random collection of isolated sayings. Instead, a certain unity has resulted from the way these sayings and clusters of sayings have come together. In the early formative stage of the Sayings Gospel $Q$ sapiential material has been formed together from existing individual aphorisms as well as clusters of aphorisms. This grouping of sapiential material produced six blocks of material, which are characterized as six sapiential speeches. An analysis of the six sapiential speeches demonstrates that they do indeed form a loose unity, having the same overall perspective, namely to present the requirements for discipleship and to exhort those who have entered the kingdom to embark on a specific way of life. The communication of this wisdom is presented as given by Jesus to his followers as a means of showing them how they are to lead their lives as disciples who have entered the kingdom. The six speeches reflect different aspects of this theme of life as disciples of the kingdom:

SPEECH ONE (The inaugural speech)

On the life of the disciple (Q 6:20b-49);

\section{SPEECH TWO}

Discipleship and mission (Q 9:57-60[61-62]; 10:2-16, 21-24);

\section{SPEECH THREE}

Discipleship and prayer (Q 11:2-4, 9-13);

SPEECH FOUR (Discipleship demands)

Trust in God; be not afraid (Q 12:2-12);

SPEECH FIVE (Discipleship demands continued)

Trust God amidst the care of daily life (Q 12:22-34); and

SPEECH SIX (Teaching on discipleship)

The status and conduct of a disciple (Q 13:24 [13:25-30], [34-35]; [14:16-24]; 14:2627 ; $17: 33 ; 14: 34-45 ; 15: 4-7,8-10 ; 16: 13,18 ; 17: 1-6)$.

\subsection{The audience of the sapiential speeches}

These six sapiential speeches are addressed first and foremost to a community. The tone of the speeches is largely hortatory with the intention of providing instruction they do not by and large offer threats and condemnations. They are characterized by the simple, direct commands or exhortations that they offer. Appeals are often made to experience or to aspects of daily observation. While many of the sayings may have originated from wandering (wisdom) preachers and may have been addressed to them, the audience is the Q community itself (Kloppenborg 1987:239). 


\subsection{Sapiential forms}

The characteristic form of these six speeches is the wisdom saying. These are expressed as imperatives with or without a clause giving a reason. Coupled with these are the rhetorical questions which make an appeal to common sense (Q 6:32$35 ; 11: 11-13 ; 12: 6-7,23,25)$, as well as appeals to observation of nature (Q 6:35c; 12:6-7, 24, 25, 26-28, 30, 33). Beatitudes, proverbs, wisdom sayings, parables - all are to be identified throughout these speeches.

\subsection{Eschatological dimension of these speeches}

The eschatological dimension of these sayings is most revealing. The concern is above all with the presence of the kingdom. All the sayings are related to its announcement and issue a call to the disciples to participate in the presence of this kingdom (Koester 1990:239) These sermons are compositions of aphoristic wisdom sayings which provide instruction on the radical way of life demanded of one who belongs to the kingdom. As such they are not simply wisdom sayings, but ones that have an eschatological significance.

While $\mathrm{Q} 1^{16}$ does continue traditional wisdom teaching, there are two specific differences when compared to traditional wisdom. In the first place the ethical demands of the Sayings Gospel $Q$ are far more radical than those found in traditional wisdom teaching. Secondly, the wisdom of the Sayings Gospel $Q$ is addressed to a community in whose life the kingdom is present (not to an individual who follows the advice of a teacher or father).

Jesus demands a demonstration of the belief of the kingdom's presence by the community which is governed by new ethical principles. What must ultimately be the guiding force of those members of the kingdom must be their trust in God, a trust that demonstrates itself at every moment of their existence. Living in the eschatological age, they believe themselves to be strengthened by God's supporting presence.

\subsection{Concerns of the disciples of the kingdom}

As members of the kingdom a number of important concerns influence the lives of the disciples. These concerns run like golden threads throughout the sapiential speeches. Chief of these concerns is the value that is placed on poverty. It is possible, as Kloppenborg (1987:240) implies, that the community could have designated itself as 'the poor'. The poverty that they embraced even outdid that of the Cynic preachers (the Cynics at least were permitted to carry a purse and a staff).

The imitation of God is another important theme: this is demonstrated by the renunciation of any form of violence, and the extension of forgiveness and mercy to all. 
Discipleship is also very radical in the extreme. It involves the renunciation of all ties, particularly family ties, and the embracing of homelessness and martyrdom. This theme of discipleship permeates everyone of the speeches. The instructions aim at equipping the disciples in their lives as members of the kingdom. For this reason attention is given to every aspect of the life of the disciple. The six sapiential speeches demonstrate the different aspects of the life of a disciple of the kingdom, such as mission; prayer; trust in God; cures of daily life; and the status and conduct of a disciple. Undoubtedly the belief in the presence of the kingdom among them provided the impetus to embrace these radical demands. Again the eschatological has impregnated the sapiential dimension.

The formative element of $Q$, then, was a collection of sapiential speeches with an eschatological appeal to be aware of the presence of the kingdom. It is assumed that these speeches were already in a written form before they underwent a transformation through a further redaction. I shail now turn to examine what this new direction contributed to the Sayings Gospel $Q$.

\section{THE APOCALYPTIC REDACTION OF THE SAYINGS GOSPEL $Q$}

The six sapiential sermons discussed in the previous chapters underwent a redaction giving them a specific direction. This redaction took place, not only through the insertion of sayings within the six sapiential speeches, but also through the insertion of a number of united clusters of sayings forming blocks in their own right. Four important elements emerge in this redaction ${ }^{17}$ :

- a call to repentance;

* an announcement of judgment over 'this generation';

* the apocalyptic expectation of the return of the 'Son of Man'; and

- the roles of John and Jesus.

In addition to the insertions made to the six instructional sapiential speeches of Q1 there are five blocks of material that incorporate the above elements and give a new direction to the $\mathrm{Q} 1$ foundational document. The five blocks are:

- John's preaching (Q 3:7-9, 16-17);

- healing of the centurion's servant and sayings about John (Q 7:1-10 and 18-35);

- the community in conflict: the Beelzebul accusation and the woes against the Pharisees (Q 11:14-52);

* the coming judgment (Q 12:39-59); and

* the parousia and the coming of the Son of man (Q 17:23-37).

These five complexes of $Q$ sayings, which have been organized into five speeches, account for about one-third of the bulk of $Q$ (see Kloppenborg 1987:166). 


\subsection{The audience of these sermons of judgment}

The actual audience of these speeches is the $Q$ community itself (Kloppenborg 1987: 167). However, in speaking to them, the speaker has a more urgent audience in mind, namely the opponents of the $\mathrm{Q}$ community. The opposition of those outside the community was the context for the development of this redaction of $Q$. A con-

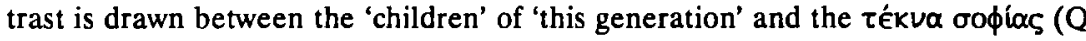
7:31-35).

Here the great shift occurred between Q1 and Q2. Whereas the audience for $\mathrm{Q} 1$ was the $\mathrm{Q}$ community itself, the audience for $\mathrm{Q} 2$ also embraced those outside the community, their opponents. In this sense the audience for Q2 includes Israel as a whole ( = 'this generation' $Q 7: 1-10,31-35 ; 11: 29-32,49-51)$. The redactor does not really envisage that Israel will repent - the tone of the speeches is such that Israel appears totally impenitent.

These sayings of $\mathrm{Q} 2$ demonstrate how the identity of the community is now being forged in so far as it separates itself off from the rest of Israel. Boundaries are now being established between them and the rest of Israel. This conforms to what we know about Judaism of the time of the first century CE. Judaism was going through a period of great transformation with numerous groups and sects calling for the heart of Israel (Neusner 1978:177-191). In the community of Q2 we have one such group which claims to be the true Israel and calls all those outside to change their way of life (Kloppenborg 1987:167-168).

\subsection{Forms}

Whereas the instructional layer of $\mathrm{Q} 1$ was expressed predominantly by means of wisdom sayings, this series of five speeches employs a number of different forms.

Two miracle stories are contained as a prelude to two of the speeches $(Q$ 7:1-10; $Q$ 11:14-23). The miracle is narrated not so much for itself, for $Q$ is not really interested in the miraculous, but the miracle helps illustrate the teaching that is contained in the respective speeches.

Kloppenborg argues rightly that the miracles in fact belong to that category of forms termed chriae: 'The miracle stories which are selected function as chriae, that is, as short, pithy sayings which are given a brief introduction or setting. They fall into the class of chriae which Theon of Alexandria terms xpeial drookpı sponsorial chriae), or sayings which are elicited in response to some circumstance (Kloppenborg 1987:168).

In fact the chriae have been used throughout the speeches to bring together the various sayings: Chria appended sayings 3:7-9 + 16-17; 7:18-23 + 24-26; 7:24-26 + 27, 28, (31-35); 11:14, 15, 17-18a + 19, 20, 21-22, 23, 24-26; 11:16, $29+30,31-32,33$, 34-36 (Kloppenborg 1987:168). 
The various sayings which are brought together by these chriae are predominantly judgment sayings and apocalyptic words (Kloppenborg 1987:169). In particular they are used as a response to a specific situation (Kloppenborg 1987:169). In this they appear as chriae. For example, the judgment that John proclaims is a response to those who come to hear his preaching (Q 3:7-9).

\subsection{Eschatological dimension}

While the eschatological dimension of the instructional sayings of $Q 1$ was related to the presence of the kingdom of God and was a challenge to accept the presence of this kingdom in the preaching of the itinerant $Q$ preachers, with $Q 2$ the eschatological viewpoint has changed to the future. Its focus rests on the coming kingdom inaugurated by the Son of man which will usher in a profound judgment, rewarding the members of the $Q$ community, but bringing severe punishment on impenitent Israel, on 'this generation'.

\subsection{Theme of judgment}

The theme of judgment runs throughout the redaction. John issues a call to repentance when faced with an imminent judgment (Q 3:3-9). It is especially the imminent nature of the judgment which is stressed (Q 3:17 'His winnowing fork is in his hand, to clear the threshing floor and to gather the wheat into his granary.) The judgment is one that is passed against 'this generation' ('Yes, I tell you it will be charged against this generation' $Q$ 11:51). The basis for this judgment and condemnation rests in the failure to heed the call to repentance $(Q 3: 7 b-9 ; 11: 31-32)$. John and Jesus are the emissaries of Sophia, who now calls 'this generation' (Q 11:29) to repentance ( $Q$ 3:7b-9; 11:31-32). In fact the rejection of John's and Jesus' preaching is a rejection of Sophia and the basis for judgment ( $Q$ 7:31-35; 11:19-20, 24-26, 2932, 33-36, 49-51; 12:57-59). Besides an imminent judgment these spokespersons for Sophia proclaim the coming of the parousia which will involve all people. It will occur suddenly and without warning (Q 12:39-40; 17:26-27, 28-30, 34-35).

\section{HOW APOCALYPTIC IS THIS REDACTION?}

Käsemann's (1969:82-107) famous saying that 'apocalyptic was the mother of all Christian theology' has had an enormous influence on the way in which scholars perceive the origins of Christianity. While apocalyptic certainly did have an important influence in the development of early Christianity, it is a distortion to label it 'the mother' for by that term one implies that it gave birth to all other theologies. This simply is not the case. For example, the instructional layer of the Sayings Gospel $Q$ has been heavily influenced by wisdom, which bears no relationship to apocalyptic. 
Four characteristics have been noted as marking the redaction of Q2. These marks were identified as:

* a call to repentance;

- an announcement of judgment over 'this generation';

- the apocalyptic expectation of the return of the 'Son of Man'; and

- the roles of John and Jesus ${ }^{18}$.

Since only one of the above features is strictly identified as 'apocalyptic', in what way can this whole redaction of the Sayings Gospel Q be identified as an 'apocalyptic redaction'? Horsley (1991:195-209) has raised a number of objections to the 'apocalyptic' designation of $Q$. His main criticism stems from the fact that the characteristics of 'apocalyptic' are not found throughout all the five speeches of Q2. He even goes so far as to say that 'it is difficult to find in these five complexes motifs that could be identified as apocalyptic' (Horsley 1991:197). It is important to take a brief overview of these five speeches of $\mathrm{Q} 2$ to examine their apocalyptic orientation, to see in how far one can speak of an apocalyptic redaction. This is all the more necessary given Horsley's critique.

\subsection{John's sermon of repentance ( $Q$ 3:7-9 and 16-17)}

John begins his proclamation with a threat of judgment (Q 3:3-7). This leads to an apocalyptic prediction (Q 3:16-17) which speaks of one who is to come (ó épxó $\mu \epsilon-$ $v \circ$ ) who will exercise this judgment with fire and offer salvation to those who have been faithful. These descriptions are truly apocalyptic for they are reminiscent of Old Testament apocalyptic descriptions of the carrying out of future divine judgment: 'His winnowing fork is in his hand, to clear his threshing floor and to gather the wheat into his granary, but the chaff he will burn with unquenchable fire' ( $Q$ 3:17).

62 Healing of the centurion's servant and Jesus' sermon on John (Q 7:1-10 and 18$23,24-26,(16: 16), 31-35)$

Two of the four elements so characteristic of Q2 predominate, namely the announcement of judgment; and the roles of John and Jesus in this judgment over this generation. The announcement of judgment is the most noteworthy aspect of this block of sayings: Jesus directly attacks this generation, when he says: "To what shall I compare the people of this generation, and what are they like'? (Q 7:31). The apocalyptic description of judgment, so characteristic of the apocalyptic imagination is in actuality missing here. However, the importance given to judgment by this section can be seen to presume indirectly the coming eschatological judgment. While direct apocalyptic descriptions do not feature, this section does take its force and impetus from a belief in the coming judgment. 
6.3 Jesus' speech against this generation ( $Q$ 11:14-26, 29-32, 33-36, 39-52)

When one returns to the characteristic features of Q2, one notices that it is the aspect of the condemnation of 'this generation' that occupies the main concern of the entire speech. As regards the other characteristics, this speech is surprisingly silent. There is undoubtably a call to repentance which is offered in an indirect way. And in fact once one reaches the woes against the Pharisees it almost appears that there is no hope for any form of repentance from the Pharisees. All that remains is the inevitability of judgment. The apocalyptic imagination has also not exercised much of an influence upon this speech. The indirect presumption of judgment lies in the background.

\subsection{Threat of apocalyptic judgment ( $Q$ 12:39-40, 42-46, 49, 51-53, (54-56), 57-59)}

This apocalyptic speech of Jesus (Q 12:39-59) is stamped by dire warnings of impending judgment. The apocalyptic imagination is evident throughout and conforms to the apocalyptic expectation of a coming judgment and punishment of those who are unfaithful. The coming of the Son of man will usher in this period of judgment and destruction.

6.5 The parousia and the coming of the Son of man (Q 17:23, 24, 26-30, 34-35, 37; 19:12-27; 22:28-30)

This speech gives forceful expression to the coming judgment of the Son of man. Apocalyptic features dominate here more than in any of the other speeches of Q2. The apocalyptic images are very graphic: lightning flashing across the sky at the coming of the Son of Man (Q 17:24); fire and sulphur rained down in the destruction of Sodom (Q 17:29).

\subsection{The theological basis for the redaction of Q1}

The above examination shows that in three out of the five $Q 2$ speeches the apocalyptic imagination is evident. Even in those two speeches where direct apocalyptic references are not evident, one can argue that a presumption of an apocalyptic judgment is essential to appreciate the threat of judgment that is evident therein.

However, while one can speak of an apocalyptic influence, as has been demonstrated above, I do not think that it is sufficient to account for the whole redaction of Q2 whereby a literary unity ${ }^{19}$ is given to the Sayings Gospel Q. In such an apocalyptic redaction, which achieves a literary unity, one would expect to find the apocalyptic element emphasized much more than it has been. And not just emphasized, but actually being that principle that gives organic unity to the whole work. In this I think the critique of Horsley has been to a certain extent valid. This is not to 
deny the importance that the apocalyptic imagination does play in this redaction, but I think it should be seen as part of something wider, rather than as constituting the major part of the redaction.

The above examination has shown that it is especially the theme of judgment, and imminent judgment at that, which runs like a golden thread throughout the redaction. In this sense I think that the direction opened up by Steck (1967:286) and endorsed by Jacobson (1992:72-76) makes, to my mind, the best sense of the material. Instead of speaking of an apocalyptic revision of $Q 1$, one should rather see $Q 1$ as undergoing a re-interpretation within the framework of a deuteronomistic perspective of history. Herein one can still see the apocalyptic imagination playing a part, but it is only a part of the wider framework of the deuteronomistic understanding of history. It is this latter perspective which is able to give an organic unity to the whole work.

The deuteronomistic perspective of history sees Israel's history against the backdrop of Israel's disobedience, which is always followed by a call to repentance. This she accepts only to be followed later by beginning again the cycle with disobedience and rejection against God. When Israel repents, God restores her by gathering those who had been scattered among the nations. It was Steck who has largely been responsible for showing how this deuteronomistic conception of history continued throughout Israelite thought. He saw the hasidic movement of 250-200 BC as being responsible for continuing the deuteronomistic outlook by uniting divergent groups against the threat of Hellenization (Steck 1967:206-212). After $150 \mathrm{BC}$ the Hasidic movement's thrust was taken over by other groups (Steck 1967:212).

Against this background the Sayings Gospel $Q$ is also seen to bear strong influences from the deuteronomistic tradition. Jacobson ${ }^{20}$ presents a very good summary of these influences. Basing himself on Steck he shows how seven characeristics of the deuteronomistic tradition are clearly evident in the Sayings Gospel $Q$. The wisdom dimension of the sayings of Jesus has been thoroughly stamped by this deuteronomistic prophetic tradition. In doing so the $Q$ community saw itself called to remain faithful at the end of time while awaiting the return of the Son of man (Hartin 1991:77) In contrast to them the majority of the nation of Israel appeared to be unconcerned with the seriousness of the present moment. They are also referred to as 'this generation' ( $Q$ 11:31) who identify themselves with other evil generations who persecuted the prophets. Belonging to the line of prophets, the $Q$ community sees itself in its turn as being persecuted by 'this generation'. Conseq'antly, the Sayings Gospel $Q$ bears witness to the realization among the $Q$ community of its distinction from the nation of Israel. In fact it sees itself as the loyal group, while Israel is judged to be the impenitent nation. 
The deuteronomistic framework becomes the overarching theological perspective for the Sayings Gospel Q: it brings together the other dimensions of wisdom, prophecy, apocalyptic and Divine Sophia within the overriding viewpoint of a notion of history in which the people of Israel are called to repentance. However, within this nation only the $Q$ community heeds this call.

The four characteristics of this redaction, as referred to previously, support this deuteronomistic theological outlook:

- the call to repentance is a key theme of the deuteronomistic movement;

- 'the announcement of judgment to 'this generation' conforms to the condemnations uttered against those who do not heed the call to repentance;

- the apocalyptic expectations of the coming of the Son of man also function within this deuteronomistic view of history as the final moment of judgment exercised against those who remained faithless; and

- the roles of John and Jesus function as those spokesmen, the prophets, who had constantly called upon their people to heed the call to repentance.

This overarching theological stamp helps also to make sense of a number of aspects of the Sayings Gospel Q:

- The absence of any mention of the passion, death and resurrection of Jesus is understandable against this background. The center of interest is not in the salvific nature of Jesus' death (as in other canonical traditions), but rather in the impenitence of Israel (Jacobson 1992:74). The rejection of Jesus, John, the prophets, the $Q$ community, signals this hardness of heart of Israel, 'this generation'.

- The importance of John's role is not to prepare the way for Jesus. Rather, he becomes an independent messenger calling Israel to repentance.

- The apocalyptic imagination is used to give expression to the ultimate consequences of failure to heed the call to repentance. The final outcome of infidelity will result in a judgment which is conceived of as imminent, brought about by the imminent return of the Son of man.

* The Wisdom sayings of the instructional layer of Q1 take on a new dimension. They become the illustration of the type of life that is required of those who have accepted the call to repentance. They demonstrate the style of life of those who are different from 'this generation'.

- Within the deuteronomistic perspective the notion of wisdom also undergoes a major development. In the instructional layer emphasis was placed on practical wisdom instruction for one's ethical life. Now in Q2 Wisdom is personified and 
exercises the role of Divine Wisdom who sends out emissaries calling on Israel to repent. Divine Wisdom becomes a further illustration of the deuteronomistic tradition. In five passages in the Sayings Gospel Q (Q7:31-35; 10:21-22; 11:31; 11:49-51; 13:34-35) the Old Testament tradition of Divine Sophia is reflected. While only two passages within the Sayings Gospel $Q$ refer directly to the figure of Divine Sophia (Q7:31-35 and Wisdom's Oracle in Q 11:49-51), three other passages (Q 10:21-22; 11:31; 13:34-35) also presume this tradition of Divine Sophia for their argument.

\section{SIGNIFICANCE OF WISDOM AND DEUTERONOMISTIC LAYERS OF THE SAYINGS GOSPEL $Q$}

Recent studies on the Sayings Gospel $Q$ have opened up exciting new ways for viewing the development of the movement from Jesus to the Synoptic Gospels. Through the influence of Schweizer the emphasis had been placed on an apocalyptic Jesus. Previously, the line of development was presented as running from the apocalyptic John and his disciples through Jesus, who himself was apocalyptically orientated, and then on into the traditions of the early church in a monolithic straight line. However, from these studies on the layers of the Sayings Gospel Q, another possible and more likely scenario can be painted. Jesus is a wisdom teacher, who early on left the apocalyptic movement of John, to preach a message that gave instruction for the daily life of its hearers, what is termed wisdom advice in relation to the Hebrew Scriptures. It was this instructional message which formed the basis for the development of the Sayings Gospel Q.

What this is saying is that the trajectory began apocalyptically with John and the message that he proclaimed. Then it moved in a new direction with the instructional wisdom proclamation of Jesus. This wisdom proclamation formed the heart of the Jesus saỹings that were transmitted, and it formed the basis for the establishment of a $Q$ community for whom these sayings were important and reflected their very essence. The apocalyptic tradition is one that grew up elsewhere - Paul gives witness to an apocalyptic thrust, as did Mark. In some ways the development of apocalyptic elsewhere in early Christian centers is to be seen to be connected with the emphasis upon the death and resurrection of Jesus. If Jesus is risen from the dead, then the eschatological age has commenced, inaugurating a time of expected judgment.

Since the time of Nag Hammadi it is no longer possible to claim, as the early Fathers of the Church did, that in the beginning everything was unity and orthodoxy, and then heresy arose. The opposite seems to be the case, or rather that in the beginning there was multiplicity and diversity and that only later a distinction was made as regards what was orthodoxy and what was heresy. 
This leads one to propose a view that Jesus said and did things that could and were interpreted in diverse ways by those who followed him, particularly later in the transmission of the Jesus traditions. This has led Crossan to postulate, in place of the criterion of dissimilarity ${ }^{21}$, a criterion of adequacy as the first principle in historical Jesus research ${ }^{22}$.

This insight of Crossan is most valuable. He draws attention to the fact that one must first of all attempt to explain the diversity from the way in which the teaching and activity of Jesus were interpreted within the context of his own day. The tradition alone is not responsible for the diversity: the very message of Jesus within the context of the time is its cause. His message was of such a nature that it could be perceived in different ways. The centrality of the message was 'a proclamation of the unmediated presence of God' (Crossan 1988:125). As such the symbol of 'the kingdom of God' becomes the fitting core symbol of the proclamation of Jesus. The very nature of a symbol as well is that it lends itself to diverse understandings and interpretations. And given the context of the world of that time, the religious matrix of 'Judaism' was in a state of flux, which meant that many interpretations of their religious traditions were available ${ }^{23}$. The response that Jesus offered in his teaching to the understanding of his religion within the context of that world was but one response, albeit a significant one, alongside numerous other responses and interpretations that were being offered in that religious context. In this then it is not the right question to ask: 'Was Jesus a Pharisee, a Zealot, a Cynic'? In a certain sense there are aspects of his presentation of this unmediated presence of God which would find resonances in the lives and teachings of these various groups, but there are also aspects which distance him from them (Crossan 1988:125).

Returning to what has been argued previously about the understanding of the message of Jesus in the Sayings Gospel Q, two different perceptions of the message of Jesus have been united: the instructional wisdom message of Jesus the sage; and the deuteronomistic message of Jesus the harbinger of judgment, which incorporates an apocalyptic element of imminent judgment. While the apocalyptic imagination originated in the context of the early church, this is not to say that it is an 'invalid development'. The criterion of adequacy, as indicated by Crossan (1988:125), is an adequate explanation for its development. Jesus' proclamation of the message of the unmediated presence of God gave rise to an apocalyptic appropriation by those of his followers who experienced situations of rejection. While Jesus proclaimed the message that the immediacy of God is such that it 'knew no limits of time or space' (Crossan 1988:125) there are those who appropriated this proclamation by focusing attention on the future aspect of God's immediacy and gave rise to an apocalyptic emphasis in the proclamation of Jesus. 
In other words the proclamation of Jesus is much like a prism: depending upon the light which enters the prism, the colours appear differently. The prism remains the same, but the beholder's perception of the prism changes through the light that enters it and is refracted from it. So, too, with the message of Jesus - the appropriation of his message both in the first century and in the twentieth century varies depending upon the context that the reader brings to that message.

A study of the Sayings Gospel Q has enabled us to appreciate the message of Jesus in a new light. As one of the earliest sources for the message of Jesus its importance lies in tracking the traditions of the Gospels closer to the person of Jesus. The examination of the layers behind the Sayings Gospel $Q$ has the distinct importance of showing that the proclamation of Jesus was directed first of all to the proclamation of a kingdom that was present, to the divine immediacy of God's presence. The apocalyptic understanding of a future, immediate end of the world was a later appropriation within a deuteronomistic framework that developed from sayings of Jesus which were interpreted in this way by the early Church.

\section{ENDNOTES}

1. The financial assistance of the Centre for Science Development (of the Human Sciences Research Council of South Africa) as well as the Research and Bursaries Committee (RBC) of the University of South Africa towards this research is hereby acknowledged. Their assistance made it possible for me to conduct research during my Sabbatical at the Institute for Antiquity and early Christianity at the Claremont Graduate School, as well as St Paul's University, Ottawa. Opinions expressed in this publication and conclusions arrived at, are those of the author and are not necessarily to be attributed to the Centre for Science Development nor to the RBC of the University of South Africa.

2. The exact origin of this designation is disputed, but it seems to have first been used by Johannes Weiss (1890:555-569, cf Neirynck 1978:119-125; 1979:382383).

3. Jacobson (1992:30) defines a Gospel in this way: '...if by 'gospel' we mean a document dealing with Jesus, representing a coherent theological perspective and thus capable of standing alone, then $Q$ could with some justice be pronounced a gospel'.

4. Davies says:

The words of Jesus in $Q$ point not as much to the normalities of catechetical instruction as to the moral enthusiasm of the first Christians, the 'first fine careless rapture' of a community 
which confronted and dared the impossible.... The Church had preserved a tradition of the ethical teaching of Jesus which it regarded as in itself part of the crisis wrought in his coming. To put it yet more forcefully, this teaching itself helped to constitute the crisis. Q sets the ethical teaching of Jesus in its utterly radical and critical context as part of the drawing near of the Kingdom, that is, that teaching is not primarily a catechetical necessity, or an addendum to the Gospel, but itself part of the Gospel.

(Davies 1963:386)

5. Following the method adopted by the International $Q$ Project (IQP) of the Society of Biblical Literature, texts of the Sayings Gospel $\mathbf{Q}$ are quoted by their Lukan chapter and verse enumeration. This, however, does not imply that the Lukan wording is necessarily closer to the $Q$ reading than the Matthean wording. For example $Q$ 7:35 would indicate that it is a $Q$ text which is found at Luke 7:35.

6. As Borg (1986:87) says: 'It is important to realize how central the coming Son of man sayings are for this position. Without them, there is very little in the gospels which would lead us to think that Jesus expected the end of the world soon'.

7. Robinson has in fact argued that studies recently undertaken into the Sayings Gospel $Q$ have in fact produced a Copernican revolution with regard to what it reveals about the historical Jesus:

The idea of Jesus as apocalypticist had originally commended itself in the same way as did the Copernican revolution. As an organizing principle, the theory that the earth rotates around the sun left less by way of unresolved problems than did the previous geocentric model. Apocalypticism won on the aesthetic criterion of providing a cleaner, less-cluttered model. And so it became the working hypothesis for the quest of the historical Jesus in the twentieth century....Now, almost a century later, though Schweitzer's apocalyptic derivation of Jesus has become the establishment view, it no longer plays that liberating role. As the old model, it is now frayed, blemished by broken parts, no longer a heuristic tool drawing attention to new insights on all sides, but rather a Procrustean bed in which the discipline squirms, ill at ease. 
Today's growing edges are no longer edges of that given model, but rather dangle off in space on their own, in a largely disintegrated discipline.

(Robinson 1991:189-190)

8. Steck (1967:206) presents it in this way: '...die levitische Tradition des dtrGB war diejenige Konzeption, die eine theologische Erfassung der zeitgeschichtlichen Vorgänge im Zusammenhang mit dem Anliegen der Umkehr Israels ermöglichte'.

9. Steck (1967:209-212) is of the opinion that besides the Q community renewal movements are witnessed to in texts such as the Psalms of Solomon, the Assumption of Moses, Ps-Philo, Biblical Antiquities, 4 Ezra, and the Second Apocalypse of Baruch.

10. Zeller (1977:191) identifies the six groups of sayings as follows:

I Verhalten gegenüber Feinden: (Lk 6:20-23); Mt 5:39b, 40, 42; Lk 6:31; Mt 5:44b-47; Lk 6:36; Mt 7:1, 2b, 3-5; (Lk 6:43-46; Mt 7:24-27).

II Verhalten der Boten: Lk 10:2-8a, 9-11a, 12(+16?).

III Gebet: (Lk 11:2-4?) Mt 7:7-11.

IV Verhalten in Verfolgung: (Lk 12:2ff) Mt 10:28-31; Lk 12:8f(10).

V Einstellung zum Materiellen: Mt 6:25-33, 19-21.

VI Wachsamkeit: Lk 12:(35-37?) 39f; Mt 24:45-51a.

Dazu könnte man noch die sog. Q-Apokalypse stellen, die mit Vetitiven einsetzt:

VII Verhalten vor dem Ende: Mt 24:26-28; Lk 17:26f, 30; Mt 24:40f.

11. Probably in the Transjordan-Decapolis region (Schulz 1972:481).

12. As Jacobson says:

Schulz's analysis shows that $Q$ is not, as a whole, a literary unity, and it sets before us the task of trying to account for the diversity, even, the contradictions, in the material...Schulz's analysis requires us at least to seek to make sense of each layer in Q. This means showing how the formal and material content of $Q$ are of a piece.

(Jacobson 1992:42) 
13. As Kloppenborg (1987:32-33, 38) says:

Koester observers that the forms most typical of the wisdom gospel or logoi sophon are wisdom sayings, legal pronouncements, prophetic sayings ('l'-words, blessings and woes) and parables. Least typical of this genre are apocalyptic sayings, especially apocalyptic Son of Man sayings. Therefore, as far as Gattungsgeschichte is concerned, the Gos.Thom. reflects a state antecedent to the final form of $Q$. By including Son of Man sayings, $Q$ produced a secondary version of a wisdomgospel'. Koester conjectures that the introduction of apocalyptic eschatology was a means to attenuate the radicalized eschatology and gnosticizing tendencies at work in earlier forms of $Q$.... His conclusions regarding the formative elements of $Q$ are based on two assumptions: that $Q$ belongs to the genre of 'wisdom gospel' and that only certain kinds of sayings and theological tendencies are typical of the genre. According to Koester, apocalyptic Son of Man sayings and sayings which evince a strongly future-oriented eschatology run counter to the tendencies of the genre, and for that reason are to be judged secondary. In practice Koester's method is comparative and the Gos. Thom. serves as a criterion for dividing what was formative in $\mathbf{Q}$. Gos. Thom. lacks an apocalyptic thrust and has only one (non-apocalyptic) Son of man saying (saying 86 ).

(Kloppenborg 1987:32-33, 38)

14. For example, in the recent work of Mack $(1988,1993)$.

15. See Kloppenborg (1987:102-262). For a concise breakdown of what belongs to the respective layers, see Kloppenborg, 'Literary convention, self-evidence and the social history of the Q people in Semeia 55, 101 (1991).

To the instructional layer Kloppenborg assigns:

1(a) Q 6:20b-23b, 27-49;

1(b) Q 9:57-62; 10:2-11:16;

1(c) Q 11:2-4, 9-13;

1(d) Q 12:2-7, 11-12;

1(e) Q 12:22b-31, 33-34;

1(f) Q 13:24; $14: 26-27 ; 17: 33 ; 14: 34-35$

[and probably also $1(\mathrm{~g}) 15: 4-7(8-10 ?) ; 16: 13,18 ; 17: 1-2,3 \mathrm{~b}-4,6]$. 
The second layer consists of five large blocks of sayings:

2(a) Q 3:7-9, 16-17;

2(b) Q 7:1-10, 18-28, 31-35;

2(c) Q 11:14-26 (27-28?), 29-36, 39b-44, 46-52;

2(d) Q 12:39-40, 42-46, 49, 51-59;

2(e) Q 17:23-24, 26-30, 34-35, 37b; 19:12-27; 22:28-30;

and various interpolations into Q1: 6:23c; 10:12, 13-15; 12:8-9, 10; 13:25-30, 34$35 ; 14: 16-24$.

The third layer consists of:

Q 4:1-13; 11:42c and 16:17.

16. The customary designation for the different layers of the Sayings Gospel $Q$, as identified by Kloppenborg, is:

Q1: the instructional sapiential layer;

$Q 2$ : the apocalyptic redaction; and

Q3: the further redaction with the addition of the narrative of the tempation ( $Q$ 4:1-13).

17. See Koester (1990:162) who draws attention to three of the four elements. He does not mention the call to repentance, which is an essential element of the redaction. Kloppenborg (1987:102) describes the important elements in the redaction in this way: 'The call to repentance, the threat of apocalyptic judgment and the censure of 'this generation' for its recalcitrance are prominent in several clusters of $Q$ sayings'.

18. It seems as if it is very difficult for scholars to let go of the dominance that apocalyptic has had over the thought of Jesus. Despite the studies that Kloppenborg and others have undertaken in regard to the wisdom dimension of the teaching of Jesus, many scholars still persist in naively arguing for an apocalyptic understanding of the teaching of Jesus. In a very recent article Collins (1991:220-228) argues for what one can accept as belonging to the historical Jesus. Following the methodology of Sanders she argues that one must begin with the deeds of Jesus rather than with his teaching. She implies that Jesus understood himself and his work in apocalyptic terms:

The events of Jesus' life that are generally accepted as historical, or for which one could make a sound case for historicity, imply that Jesus understood himself and was understood in an apocalyptic or restoration-eschatological context. He accepted the apocalyptic message of John the Baptist by 
going to him to be baptized. He chose twelve disciples to have a special role, apparently in relation to the notion of the renewal of the twelve tribes of Israel. He performed a prophetic symbolic action in the temple that alluded to its destruction and possibly to its replacement by the eschatological temple. He was executed by the Romans as a threat to public order, possibly for claiming to be or allowing himself to be treated as the king of the Jews (the Messiah of Israel). Shortly after Jesus was crucified, his death and subsequent vindication were interpreted by a significant and influential number of his disciples in an apocalyptic context. The origin of Jesus' activity in the apocalyptic movement of John the Baptist, the known events of his life, and the apocalyptic movement initiated by his followers after his death suggest that Jesus understood himself and his mission in apocalyptic terms.

(Collins 1991:227)

Collins' apocalyptic interpretation rests on three arguments which are all subject to question:

- The origin of Jesus' activity in the apocalyptic movement of John the Baptist. From studies of $Q$, as indicated above, the relation of John to Jesus is attributed to the second strata of $Q$ - it is a late insertion into $Q$ and hence I would conclude that the historical reliability of this is open to question.

* Among the known events of his life among which Collins includes the calling of the twelve disciples for the purpose of 'the renewal of the twelve tribes of Israel'. Once again, the relationship of the disciples to the twelve tribes of Israel is reserved to the second strata of Q: 'I confer on you, just as my father has conferred on me, a kingdom, so that you may eat and drink at my table in my kingdom, and you will sit on thrones judging the twelve tribes of Israel ( $Q$ 22:29-30)'.

- Collins speaks about 'the apocalyptic movement initiated by his followers after his death'. The implication of this is that immediately after Jesus' death his followers began proclaiming an apocalyptic message. This is far from demonstrated. Again, following $Q$ one can see that the apocalyptic dimension, if we can call it that, only came onto the scene in the second phase. 
The point I wish to make is that Collins has not taken into account the research that is being done on Jesus' traditions, particularly those related to $Q$. What she has confidently asserted as belonging to the historical Jesus is far from sure and in fact has been contradicted by recent $Q$ studies. From these studies on the Sayings Gospel $Q$ it is far from sure that Jesus looked upon himself in an apocalyptic or restoration-eschatological context' (Collins 1991:227).

19. Literary unity has been defined as 'the concept that a literary work shall have in it some organizing principle in relation to which all its parts are related so that, viewed in the light of this principle, the work is an organic whole' (see Thrall \& Hibbard 1962:500).

20. Jacobson (1992:73) summarizes Steck's position in this way:

(a) The whole history of Israel is pictured as one of persistent disobedience (see Q 6:23c; 11:47-51; 13:34-35; 14:16-24);

(b) Therefore Yahweh again and again sent prophets to call Israel to return, to repent (see Q 11:47-51; 13:34-35; 14:16-24);

(c) Israel always rejected these prohpets, even killing them (see $Q$ 6:23c; 11:47-

51; 13:34-35; 14:16-24);

(d) Therefore Yahweh punished, or will punish, Israel (see Q 11:47-51; 13:3435);

(e) But now a new call for repentance is issued (see Q 3:7-9, 16-17; 6:20-49; 10;2-12; 7:31-35; 11:29-32; 11:39-52);

(f1) If Israel repents, Yahweh will restore her, gathering those scattered among the nations; and

(f2) Yahweh will bring judgment upon Israel's enemies. In $Q$, the many statements about the kingdom of God and the son of man take the place of element (f1).

21. Conzelmann (1973:16) expressed this criterion of dissimilarity in this way: 'Whatever fits neither into Jewish thought nor the views of the later church can be regarded as authentic'.

22. Crossan (1988:125) says:

My proposal is to make a virtue of diversity and to formulate my basic question like this: what did Jesus say and do that led, if not necessarily at least immediately, to such diverse understandings?...This formulation suggests an alternative first principle to the criterion of dissimilarity, namely, the criterion of adequacy: that is original which best explains the multipli- 
city engendered in the tradition. What original datum from the historical Jesus must we envisage to explain adequately the full spectrum of primitive Christian response. If, for example, Jesus' words can be invoked for or against legal observance, what must have been said that could be so divergently interpreted? It is clear, therefore, that I no longer imagine an answer to this question that assumes Jesus did observe strict or even Pharisaic legal norms, and that later some of his followers created sayings to the contrary. Nor do I any longer imagine an answer assuming Jesus to be lax, liberal, humanistic, or anarchic, and that subsequently some of his followers created sayings to the contrary. I am trying to imagine words and deeds that could have been, plausibly and persuasively, sincerely and honestly, interpreted in both directions by different followers at the same time.

(Crossan 1988:125)

23. As Neusner (1984:29-30) expresses it:

For this period, however, no such thing as 'normative Judaism' existed, from which one or another 'heretical' group might diverge. Not only in the great center of the faith, Jerusalem, do we find numerous competing grooups, but throughout the country and abroad we may discern a religious tradition in the midst of great flux. It was full of vitality, but in the end without a clear and widely accepted view of what was required of each individual, apart from acceptance of mosaic revelation. And this could mean whatever you wanted.

(Neusner 1984:29-30)

\section{Works consulted}

Borg, M 1986. A Temperate Case for a non-eschatological Jesus. Forum 2/3, 81102.

Bornkamm, G 1956. Jesus von Nazareth. Stuttgart: Kohlhammer.

Chilton, B 1984. The Kingdom of God in the teaching of Jesus. Philadelphia: Fortress Press.

Collins, A Y 1991. The apocalyptic Son of man sayin ${ }_{b}$, in Pearson, B A (ed), Future of early Christianity: Essays in honor of Helmut Koester, 220-228. Minneapolis: Fortress. 
Conzelmann, H 1957. Gegenwart und Zukunft in der synoptischen Tradition. ZTK 54, 277-296.

1973. Jesus. Philadelphia: Fortress.

Crossan, J D 1988. Divine immediacy and human immediacy towards a new first principle in historical Jesus research. Semeia 44, 121-140.

Davies, W D 1963. The setting of the sermon on the mount. Cambridge: Cambridge University Press.

Dodd, C H 1961. The parables of the kingdom. New York: Charles Schribner's.

- 1971. The founder of Christianity. London: Collins.

Hartin, P J 1991. James and the Q Sayings of Jesus. Sheffield: Sheffield University Press.

Horsley, R 1991. Logoi propheton? Reflections on the genre of Q, in Pearson, B A (ed), The future of early Christianity: Essays in honor of Helmut Koester, 129-209. Minneapolis: Fortress.

Jacobson, A 1992. The first gospel: An Introduction to $Q$. Sonoma: Polebridge.

Käsemann, E 1969. The beginnings of Christian theology: New Testament questions of today. London: SCM.

Kloppenborg, J S 1987. The formation of Q: Trajectories in ancient wisdom collections. Philadelphia: Fortress.

Koester, H 1971. One Jesus and four primitive gospels, in Robinson, J M \& Koester, H, Trajectories through early Christianity, 158-204. Philadelphia: Fortress.

- 1990. Ancient Christian gospels: Their history and development. London: SCM.

Kümmel, W G 1975. Introduction to the New Testament. Tr by H C Kee. Nashville: Abingdon.

Leivestad, R 1971. Exit the apocalyptic Son of man. NTS 18, 243-267.

Lindars, B 1984. Jesus Son of man. Grand Rapids: Eerdmans.

Lührmann, D 1969. Die Redaktion der Logienquelle. Neukirchen-Vluyn: Neukirchener. (WMANT 33.)

Lundström, G 1963. The kingdom of God in the teaching of Jesus. Edinburgh: Oliver and Boyd.

Mack, B 1988. A myth of innocence: Mark and Christian origins. Philadelphia: Fortress.

Neirynck, F 1978. The symbol Q (=Quelle). Ephemerides Theologicae Lovanienses 54, 119-125.

- 1979. Once more: The symbol Q. Ephemerides Theologicae Lovanienses 55, 382-383.

Neusner, J 1978. Comparing Judaisms. History of Religions 18, 177-191.

— 1984. Judaism in the beginning of Christianity. Philadelphia: Fortress. 
Perrin, N 1963. The kingdom of God in the teaching of Jesus. Philadelphia: Westminster Press.

- 1967. Rediscovering the teaching of Jesus. New York: Harper \& Row.

Piper, R A 1989. Wisdom in the Q-tradition: The Aphoristic teaching of Jesus. Cambridge: Cambridge University Press. (SNTSMS 61.)

Robinson, J M 1991. The Q trajectory: Between John and Matthew via Jesus, in Pearson, B A (ed), The future of early Christianity: Essays in honor of Helmut Koester, 173-194. Minneapolis: Fortress.

Schillebeeckx, E 1979. Jesus: An experiment in Christology. New York: Seebury.

Schweitzer, A 1913. Geschichte der Leben-Jesu-Forschung. Tübingen: Mohr.

Steck, O H 1967. Israel und das gewaltsame Geschick der Propheten: Untersuchungen zur Uberlieferung des deuteronomistischen Geschichtsbildes im Alten Testament, Spätjudentum und Urchristentum. Neukirchen-Vluyn: Neukirchener Verlag. (WMANT 23.)

Schulz, S 1962. Q: Die Spruchquelle der Evangelisten. Zurich: Theologischer Verlag.

Thrall, W F \& Hibbard, A 1962. Handbook to literature. New York: Odyssey.

Tödt, H E 1959. Der Menschensohn in der synoptischen Uberlieferung. Gütersloh: Mohn.

Vermes, G 1973. Jesus the Jew. New York: Macmillan.

Vielhauer, P 1965. Aufsätze zum Neuen Testament. Münich: Kaiser. (TBÜ 31.).

Von Rad, G 1965. Theologie des Alten Testaments, Vol 2. Münich: Kaiser.

Weiss, J 1890. Die Verteidigung Jesu gegen den Vorwurf des Bündnisse mit Beelzebul. Theologische Studien und Kritiken 63, 555-569.

Zeller, D 1977. Die weisheitlichen Mahnsprüche bei den Synoptikern. Würzburg: Echter Verlag. (Forschung zur Bibel 17.)

- Redaktionsprozesse und wechselnder 'Sitz im Leben' beim Q-Material, in Delobel, J (ed), Logia: Les Paroles de Jésus - the sayings of Jesus, 395-409. Louvain: Leuven University Press. (BETL 59.) 